\title{
THE VALIDITY OF EXTRA-MAJORITY VOTING REQUIREMENTS FOR THE FILLING OF BOARD OF DIRECTOR VACANCIES
}

Jacobson v. Moskowitz ${ }^{1}$ involves a conflict in application between two provisions of the New York Business Corporation Law: section 709(a) ${ }^{2}$ which allows greater than majority vote and quorum requirements in corporate charters and section $705(\mathrm{a})^{3}$ which provides that vacant directorships may be filled by a majority vote of the directors then in office although less than a quorum exists. Pursuant to section 709(a), the twelfth paragraph of the charter of the Five Ivy Corporation required the presence of 75 percent of the authorized directors $^{4}$ for a quorum and the votes of 75 percent of the directors ${ }^{5}$

1. 27 N.Y.2d 67, 261 N.E.2d 613, 313 N.Y.S.2d 684 (1970), affg 31 App. Div. 2d 904, 299 N.Y.S.2d 113 (1969).

2. The certificate of incorporation may contain provisions specifying either or both of the following: (1) That the proportion of directors that shall constitute a quorum for the transaction of business or of any specified item of business shall be greater than the proportion prescribed by this chapter [Unless a greater portion is required by the certificate of incorporation, a majority of the entire board shall constitute a quorum for the transaction of business or of any specified item of business, except that the certificate of incorporation or the by-laws may fix the quorum at less than a majority of the entire board but not less than one-third thereof. $\S 707$ ] in the absence of such a provision. (2) That the portion of votes of directors that shall be necessary for the transaction of business or of any specified item of business shall be greater than the proportion prescribed by this chapter [Except as otherwise provided in this chapter, the vote of a majority of the directors present at the time of the vote, if a quorum is present at such time, shall be the act of the board. $\S 708$ ] in the absence of such provision. N.Y. Bus. CoRP. LaW § 709(a) (McKinney 1963).

3. Newly created directorships resulting from an increase in the number of directors and vacancies occuring in the board for any reason except the removal of directors without cause may be filled by vote of a majority of the directors then in office, although less than a quorum exists, unless the certificate of incorporation or the by-laws provide that such newly created directorships or vacancies shall be filled by vote of the shareholders.

Id. $\S 705(\mathrm{a})$.

4. The meaning of the word "directors" as used in this portion of the twelfth charter paragraph and in section 709(a)(1) can be ascertained by reference to section 707: "Unless a greater proportion is required by the certificate of incorporation, a majority of the entire board shall constitute a quorum for the transaction of business . ..." The meaning of the phrase "entire board," can in turn be found by referring to section 702: "As used in this article, "entire board' means the total number of directors which the corporation would have if there were no vacancies," that is, the number of directors authorized in the crtificate of incorporation under section 702.

5. The meaning of the word "directors" as used in this portion of the twelfth charter paragraph and in section 709(a)(2) can be ascertained by reference to section 708: "Except as otherwise provided in this chapter, the vote of a majority of the directors present at the time of the vote, if a quorum is present at such time, shall be the act of the board." 
present at a meeting for the transaction of any business. ${ }^{6}$ Similar provisions were contained in the corporate by-laws. ${ }^{7}$ Another by-law, number 14 , allowed directors in office to choose interim directors to fill vacancies in the board. ${ }^{8}$ This by-law was similar to section 705(a) of the Business Corporation Law, although it made no mention of a majority vote being suffieient to elect interim directors.

The charter of the Five Ivy Corporation authorized five directors, but following the resignation of two directors, the board had operated for some years with only three members. ${ }^{9}$ At one meeting of Five Ivy's board there was an attempt to fill one of the vacant directorships with a Mr. Brody. The vote was two to one in favor of Brody's election, with Jacobson casting the dissenting vote. Jacobson sued ${ }^{10}$ under section 619 of the New York Business Corporation Law ${ }^{11}$ to set aside Brody's election, alleging that under the twelfth paragraph of the corporation's charter the votes of at least 75 percent of the three directors present at the meeting were required to transact the business

\footnotetext{
6. TWELFTH: (a) The number of directors who shall be present at any meeting of the directors in order to constitute a quorum for the transaction of any business shall be seventy-five (75\%) percent of the directors, and the number of votes of directors that shall be necessary for the transaction of any business at any meeting of the dircctors shall be the votes of seventy-five (75\%) percent of the directors. 27 N.Y.2d at 70, 261 N.E.2d at 614,313 N.Y.S.2d at 687 (footnote omitted).
}

7. 20. The number of directors who shall be present at any meeting of the directors in order to constitute a quorum for the transaction of any business shall be $75 \%$ of the directors. 21. The number of votes of directors that shall be necessary for the transaction of any business at any meeting of the directors shall be the votes of 75\% of the directors. Id. at 70-71, 261 N.E.2d at 614-15, 313 N.Y.S.2d at 687 (footnole omitted).

8. 14. If the office of any director or directors becomes vacant for any rcason, the directors in office may choose a successor or successors who shall hold office for the unexpired term in respect to which such vacancy occurred or until the next election of directors, or any vacancy may be filled by the stockholders at any meeting thereof. Any director may be removed either with or without cause, at any time by vote of the stockholders at any meeting called for the purpose. Id. at 70, 261 N.E.2d at 614, 313 N.Y.S.2d at 686 (footnote omilted).

9. There is a question as to whether the actions of the corporation's board during these years were valid, there being no quorum possible with only three directors in office, under the 75 percent quorum requirement of the twelfth paragraph of the Five Ivy charter.

10. The defendants were Henry Moskowitz and Euval Barrakette, Joseph Jacobson's codirectors before the election, George Brody, the newly elected dircctor, and Five Ivy Corporation. Jacobson v. Moskowitz, 299 N.Y.S.2d 113 (App. Div. 1969).

11. Upon the petition of any shareholder aggrieved by an election, and upon notice to the persons declared elected thereat, the corporation and such other persons as the court may direct, the supreme court at a special term held within the judicial district where the office of the corporation is located shall forthwith hear the proofs and allegations of the partics, and confirm the election, order a new election, or take such other action as justice may require. N.Y. Bus. CoRP. LAw $\S 619$ (McKinney 1963). 
of electing Brody, whereas the affirmative votes of only 67 percent-two out of three-of the directors present were in fact obtained. Jacobson apparently reasoned that by-law 14 would, for the purpose of filling a vacant directorship, dispense with the 75 percent quorum requirement which otherwise would require the attendance of 75 percent or four of the five authorized directors. While by-law 14 deals with the quorum requirment for a meeting of the board to fill vacant directorships, it does not suggest a percentage vote requirement to elect such directors once a quorum has been established. Jacobson would look to the normal vote requirement "for the transaction of any business" in charter paragraph twelve. Its provision of a 75 percent vote requirement would effectively mandate the concurrence of all three directors present at the meeting in order to put a new director into office.

The New York Court of Appeals affirmed the decision of the two lower courts ${ }^{12}$ in upholding the election of Brody. The election came within the literal language of section 705(a): a vacancy "occurring in the board . . . [was] filled by vote of a majority [two out of three] of the directors then in office, although less than a quorum exist[ed]." The specification of a majority vote in section 705(a), however, would appear to be in conflict with the authorization in section 709(a) and the implementation in Five Ivy's charter of a greater than majority vote requirement. The court felt that section 705 (a) took precedence over section 709(a) and the charter provision for two reasons. First, as a matter of statutory construction, specific provisions should control more general ones. Thus section 705 (a) which specifically governs voting to fill board vacancies should prevail over section 709 (a) which regulates voting generally, upon the transaction of any business. ${ }^{13}$ The second line of reasoning pursued by the court began with the proposition that the high quorum and high vote requirements in the charter are "completely interrelated and interdependent" so that both must either apply or be inapplicable in a given situation. ${ }^{14}$ Thus, if the high vote requirement is to be applicable, the high quorum requirement must also be applicable. But, if the high quorum requirement operates in this instance, four directors of the five

12. Jacobson v. Moskowitz, 31 App. Div. 904, 299 N.Y.S.2d 113 (Ist Dept. 1969); unreported, The Supreme Court, Special Term, New York County, Francis J. Bloustein, J., October 8, 1968.

13. 27 N.Y.2d at $69-70,261$ N.E.2d at $614-15,313$ N.Y.S.2d at 686-87.

14. Id. at 71,261 N.E.2d at 615,313 N.Y.S.2d at 687. 
authorized must be present to convene a board meeting. Since "no quorum could ever be formed from the board of three"1s then in office, the corporation would be placed in a state of "futility" 16 and stalemate. Therefore, in order to preserve the corporation's vitality and avoid its paralysis and dissolution, the requirement of a simple majority vote for the filling of vacant directorships as specified in section 705(a) must prevail over the greater than majority vote requirement allowed under section 709 (a). ${ }^{17}$ ln a dissenting opinion, Judge Jasen persuasively argued that Five lvy's high vote requirement, promulgated pursuant to section 709 (a), should prevail because section 705 (a) was intended to deal with situations where a quorum could not exist because of board vacancies, rather than with problems of corporate deadlock. ${ }^{18}$

The power to fill vacancies on the board of directors belonged to the shareholders at common law. ${ }^{19}$ In 1890, the New York Stock Corporation Law specified that vacancies on the board were to be filled "in the manner prescribed in the by-laws." 20 This statutory provision, under which a lack of prescription in the by-laws caused reversion of the right of election to the shareholders, continued in substance ${ }^{21}$ until enactment of the comprehensive Business Corporation Law in $1961 . .^{22}$ As mentioned above, section 705(a),

\section{Id.}

16. Id. at 71,261 N.E. $2 \mathrm{~d}$ at 615,313 N.Y.S.2d at 688 .

17. Id.

18. Id. at 73,261 N.E.2d at 616,313 N.Y.S.2d at 689.

19. See In re Union Ins. Co., 22 Wend. 591 (N.Y. 1840). See also 1 ABA-AL1 Model Bus. Corp. Act Annot. $\S 36$, at 605 (1960); W. CARY, Cases and Materials on Corporations 154 (4th ed. 1969); 6 Z. Cavirch, Business Organizations $\S 124.08$, at 927 (1970); 2 W. Fletcher, Private Corporations $\S 286$, at 70 (perm. ed. rev. vol. 1969); H. HenN, HANDBOOK OF THE LAW OF CORPORATIONS $\S 205$, at 411 (2d ed. 1970) [hereinafter cited as Henn]; 2 G. Hornstein, Corporation Law and Practice $§ 392$ (1959).

20. Stock Corporation Law of June 7, 1890, ch. 564, § 20, [1890] Laws of N.Y. 1069.

21. See Stock Corporation Law of May 18, 1892, ch. 688, § 20, [1892] Laws of N.Y. 1828; Stock Corporation Law of April 16, 1901, ch. 354, § 20, [1901] Laws of N.Y.964; Stock Corp. Law of April 16, 1906, ch. 238, § 20, [1906] Laws of N.Y. 470; Stock Corp. Law of Feb. 17, 1909 , ch. 61, § 25, [1909] Laws of N.Y. 20 [C. Birdseye, R. Cumming \& F. Gilbert, eds., Annot. Consol. Laws of the State of N.Y. 5751 (1909)]; Stock Corp. Law of May 24, 1923, ch. 787, $\S 55$, [1923] Laws of N.Y. 1397; Stock Corp. Law of April 12, 1929, ch. 600, § 55, [1929] Laws of N.Y. 1410; Stock Corp. Law of April 1, 1930, eh. 239, \$ 55, [1930] Laws of N.Y. 601; Stock Corp. Law of April 11, 1951, ch.717, § 6, [1951] Laws of N.Y. 1669.

22. See generally Anderson \& Lesher, The New Business Corporation Law, 33 N.Y.S. BAR J. 308, 428, 435 (1961); Andrews, The New York Business Corporation Law, 28 Albany L. Rev. 45 (1964); Hoffman, New Horizons for the Close Corporation in New York Under Its New Business Corporation Law, 28 BrookLyN L. Rev. 1 (1961); Kessler, The New York 
which was contained in the 1961 legislation, provides that a majority of the board of directors then in office, although less than a quorum, may fill vacancies occurring for any reason other than removal of directors without cause unless the charter or by-laws reserves that power to the shareholders. The rationale behind section 705(a) is that the filling of board vacancies by the directors then in office, even though not a quorum, will assure the corporation the benefit of a full board and avoid the delay and expense of convening a special meeting of the shareholders. ${ }^{23}$ Although accommodating the close corporation was a prominent goal in producing a new business corporation statute in New York, section 705 was not one of the sections addressed particularly toward that objective. ${ }^{24}$

Prior to permissive high vote and high quorum statutes, such as New York's section 709, the norm for all corporations, both close and publicly held, was that a simply majority should be the percentage required for both a quorum of the board of directors and action by the board. ${ }^{25}$ Statutes permitting high vote and high quorum requirements were addressed specifically to the oft-catalogued plight of the close corporation. ${ }^{26}$ The close corporation is the result of businessmen trying to have the best of both the worlds of partnership ${ }^{27}$ and incorporation ${ }^{28}$ and is thus referred to as an "incorporated partnership." 29 The owners of a close corporation are generally also

Business Corporation Law, 36 ST. John's L. Rev. I (1961); Stevens, New York Business Corporation Law of 1961, 47 CoRNell L.Q. 141 (1962); Symposium: New York Business Corporation Law, 11 BufFalo L. REV. 429 (1962).

23. See State of New York Joint Legislative Commttee to Study Revision of Corporation laws, Consultant's Report No. 46, Vacancies 14 (1958); $c$. Cavitch, supra note 19, at 930; G. HoRnsteIn, supra note 19, at $\$ 392$. Compare MBCA ANNot., supra note 19, at 608 with de Capriles \& McAniff, The Financial Provisions of the New (1961) New York Business Corporation Law, 36 N.Y.U.L. Rev. $1239-40$ n.6 (1961) and Henn, The Philosophies of the New York Business Corporation Law of 1961, 11 BUFFalo L. REv. 439, 440, 451 (1962) [hereinafter cited as Philosophies] and Lesher, Introduction to Symposium on New York Business Corporation Law, 11 Buffalo L. Rev. 429, 431 (1962).

24. Philosophies $442-44 \mathrm{nn} .28,29,30$. While there was no isolated portion of the N.Y. Bus. Corp. Law of 1961 governing close corporations, there were occasional sections, such as section 709 , aimed at or particularly applicable to close corporations. Id.

25. See, e.g.. HENN § 209.

26. See, e.g., Philosophies $442-44 \mathrm{nn} .28$ \& 30.

27. See text accompanying note 30 infra.

28. The corporate advantages most commonly sought include limited liability and certain tax advantages. See, e.g., HENN $\S 257$, at 507, § 258, at 509; 1 F. O'Neal, Close CORPORATIONS $\S 1.08$ (1971) [hereinaftcr cited as O'NEAL].

29. See, e.g., HENN § 257, at 506-07, § 258, at 508-09; Hornstein, Judicial Tolerance of the Incorporated Partnership. 18 LAW \& CONTEMP. PrOB. 435 (1953); Stevens, supra note 22, at 487. 
its managers and want informality in the conduct of their business affairs, a veto on corporate action, protection of salary and office against "squeeze-outs," restrictions on changes in shareholders, and a ready method of resolving disputes or obtaining dissolution if necessary. ${ }^{30}$ Despite these unique needs, corporate legislation in the United States was, until comparatively recent times, drafted with only the publicly held corporation in mind. ${ }^{31}$ The philosophy behind the older statutes was, quite naturally, more rigid and "regulatory"-concerned with protecting the public-than flexible and "enabling"-allowing the participants to structure their organization as they pleased. ${ }^{32}$ The close corporation was difficult to fit within existing statutory provisions, and the courts seldom provided sympathetic assistance. ${ }^{33}$ It was a close corporation decision, the famous Benintendi $v$. Kenton Hotel, Inc. case, ${ }^{34}$ which prompted ${ }^{35}$ the New York legislature in 1948 to adopt section 9 of the Stock Corporation Law, ${ }^{36}$ which allowed corporate charter provisions fixing high quorums for shareholders' and directors' meetings and requiring high votes for shareholder and director action. Benintendi held as invalid by-law provisions for greater than majority quorum and vote requirements, apparently on the ground that they violated public policy in making it difficult to conduct corporate business and in leading possibly to corporate paralysis. "In spite of the legislative repudiation of the Benintendi case," it has been suggesed that "it

\section{See O'NeAL § 1.12 .}

31. Id. §1.13.

32. See, e.g., Gower, Some Contrasts Between British and American Corporation Law, 69 Harv. L. Rev. 1369, 1376-77 (1956); cf. HeNN § 263, at 523; Philosophies 453.

33. See, e.g., Long Park, Inc. v. Trenton-New Brunswick Theatres Co., 297 N.Y. 174, 77 N.E.2d 633 (1948); McQuade v. Stoneham, 263 N.Y. 323, 189 N.E. 234 (1934); Manson v. Curtis, 223 N.Y. 313,119 N.E. 559 (1918).

34. 294 N.Y. 112,60 N.E. $2 d 829$ (1945).

35. See State of New York law Revision Commission, Report of the Law Revision CoMmission For 1948, at 385-86 (1948); CARY, supra note 19, at 441; N. LATTIN, R. JENNINGS \&. R. Buxbaum, Corporations Cases and Materials 318 (4th ed. 1968); O'Neal $§ 3.76$, 4.20 .

36. Act of April 6, 1948, ch. 862, § 1, [1948] Laws of N.Y. 1704. It was "[0]ne of the earliest and perhaps the most publicized statute avowedly passed to meet special needs of close corporations," although similar statutes "had been authorized in a number of states at an earlier date," e.g., Del. (1935), Calif. (1947). O'NeAL, § 1.14, at 41, 45 n. 89.31 (Supp. 1969).

37. See Op. Att'y Gen. to Dept. of State, Dec. 14, 1948, reprinted at STATE OF NEW YorK, ANNuAl Report of the AtTORNEY-General 229, 232 (1948) (Legis. Doc. (1949) No. 57); O’NEAL § 4.18. But cf. STATE OF NEW YORK LAW REvisIon COMMISSION, REPORT OF THE LAW REvision COMmission FOR 1951, at 271 (1951) (Legis. Doc. (1951) No. 65). 
would certainly be a mistake to conclude that the doctrine of that case is no longer a hazard ...."38 Section 9, as amended, ${ }^{39}$ was in substance carried over into section $709^{40}$ of the New York Business Corporation Law in $1961 .^{41}$

The New York Business Corporation Law as a whole was designed for maximum flexibility in internal corporate affairs, ${ }^{42}$ with the state taking a "laissez-faire attitude toward corporations." 43 The Model Business Corporation Act, upon which the New York Law was significantly based, ${ }^{44}$ was "prepared as an enabling statute under which a corporation may be organized and continue to exist, controlling its internal affairs . . . . It is not, and [was] not intended to be, a statute regulating [a corporation's] business or external affairs." 45 The approach of the New York Business Corporation Law is similar, although it is alleged to be "far [more] accommodating to the special problems of close corporations." 46 Because the Five Ivy Corporation is a close corporation, ${ }^{47}$ the policy of the New York Law

38. O'NeAL \$3.76.

39. Act of March 23, 1949, ch. 26I, § I, [1949] Laws of N.Y. 839; Act of April 11, 1951, ch. 717, \& 1 , [1951] Laws of N.Y. 1665.

40. It was also carried over into section 616 which provides that high quorum and high vote requirements for shareholders would be permitted if they were specified in the charter. Id. $\S 1$.

41. See State of New York Joint legislative Conmitiee to Study Revision of Corporation laws, Fifth Interim Report to 1961 Session of New York State LeGislature 70 (1961) (Legis. Doc. (1961) No. 12); O'NeAL \& I.14 n.89.29 (Supp. 1970); Kessler, supra note 22, at 44 n.194.

42. See State of New York Joint legislative Commitree to Study Revision of Corporation laws, THird Interim Report to 1959 Session of New York State Legislature 45 (1959) (Legis. Doc. (1959) No. 39); State of New York JoInt Legislative Committee to Study Revision of Corporation Laws, SECond INTERIM Report to 1958 Session of New York State legislature 43 (1958) (Legis. Doc. (1958) No. 23); State of

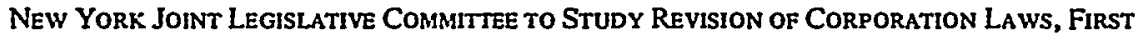
INTERIM Report to 1957 Session of New York State Legislature 50 (1957) (Legis. Doc. (1957) No. 17).

43. Philosophies 453.

44. See Philsophies 45I; cf. 1957 INTERIM REPORT, supra note 42, at 34, 45, 99, 111; 1958 INTERIM REPORT, supra note 42, at 31; 1959 INTERIM REPORT, supra note 42, at 27; Lesher, supra note 23 , at 431 .

45. Preface to 1953 Revision of Model Business Corporation Act, reprinted at 1957 INTERIM REPORT, supra note 42 , at 111 .

46. Philsophies 442, n.27.

47. "Some of these [sections of the N.Y. Bus. Corp. Law] . . - will as a practical matter be availed of only by close corporations [e.g., § 709]." Philosophies at 444. Furthermore, Five Ivy's operations were, characteristic of close corporations, informal enough to function for "some years" with only three of the five authorized directors. See note 9 supra. There is, of course, no fixed definition of the term "close corporation." See O'NEAL § 1.02. However, in a May 19, 1971 conversation with counsel for Five Ivy Corporation, he did express to this writer the opinion that Five Ivy was indeed a "close corporation." 
would seem to suggest that the participants in Five Ivy should be allowed to design, within general guidelines, their own rules of conduct for internal corporate affairs, such as meetings of the board of directors. The intent of the parties to the Five Ivy Corporation seems abundantly clear with regard to the vote of directors on "the transaction of any business at any meeting of the directors." 48 The parties apparently intended that "the votes of seventy-five (75\%) percent of the directors" be required..$^{49}$ This intent is reiterated in the by-laws ${ }^{50}$ and was not negated, and arguably therefore reinforced, by the rule designed by the parties for filling vacant directorships. That rule, by-law 14, states simply that "the directors in office may choose a successor or successors." ${ }^{1}$ The by-law does not specify a percentage vote requirement, the implication presumably being that the filling of a vacant directorship is, in the eyes of the participants, not such an extraordinary act as to require a different percentage vote than "any [other] transaction." Indeed, there does not seem to be any business reason why the parties would want a different percentage requirement, especially a lower one, for filling board vacancies, from the percentage they desired for all other acts of the board as well as for a quorum of the board and a quorum and vote of the stockholders. ${ }^{52}$ Arguably, the 75 percent was uniformly specified to insure that each faction, holding over 25 percent of the stock of Five Ivy, ${ }^{53}$ would have an effective veto in the making of corporate decisions-a veto which could not be circumvented. The court's ratification of the election of Brody effectively circumvented the Jacobson faction's veto, since, after Brody's election, a three to one vote of a four-man board or, if a fourth anti-Jacobson director were to be added to fill the fifth board vacancy, a four to one vote would be of the requisite 75 percent strength to constitute board action. The parties would probably especially want to have their veto enforced in as critical an exercise of their corporate franchise as choosing those who are to direct the future course of the corporation.

48. Five Ivy Corporation, twelfth charter paragraph (emphasis added). See note 6 supra.

49. Id.

50. Five Ivy Corporation, by-laws 20,21 . See note 7 supra.

51. See note 8 supra.

52. See Five Ivy Corporation twelfth charter paragraph, note 6 supra, and Five lvy Corporation by-law 20 , note 7 supra (as to dircctor quorum); 27 N.Y.2d at 70, n.2, 261 N.E. $2 d$ at 614 n.2, 313 N.Y.S.2d at $686 \mathrm{n} .2$ (as to shareholder quorum); personal communication with counsel for Five Ivy Corporation, May 19, 1971 (as to shareholder vote).

53. See 27 N.Y.2d at 70 n.2, 261 N.E.2d at 614 n.2, 313 N.Y.S.2d at 686 n.2. 
The reported cases involving section 705(a) are of virtually no help in construing the importance of the majority vote requirement in section 705(a) in the face of a competing higher vote provision, section 709 (a). ${ }^{54}$ The primary documents ${ }^{55}$ in the "legislative history" 56 of the New York Business Corporation Law are similarly not helpful in determining the weight to be given the majority vote provision of section 705(a). However, one document in the early stages of the Business Corporation Law's legislative history would seem to indicate that the provision in section 705(a) that the vote needed to fill board vacancies be a "majority," was a directory minimum and not intended to be mandatory in all cases. ${ }^{57}$ An analysis of the purpose of section 705 (a) tends to reinforce this inference and the conclusion that the emphasis in section 705(a) was on the words "vote of ... the directors then in office, although less than a quorum exists," rather than on the concept of a "majority" vote. The very nature of the problem of filling board vacancies suggests that because of the vacancies a quorum might not exist. The main obstacle to overcome in such a situation is that of dispensing with the strict requirement of a

54. The Jacobson court conservatively points out that the judicial authorities are "few" and "not precisely in point." Id. at 70; 261 N.E.2d at 614; 313 N.Y.S.2d at 686. Jacobson $v$. Moskowitz is truly a case of first impression. No previous reported New York case dealt with the conflict between sections 709(a) and 705(a). Moreover, the only two cases dealing with section 705(a) do not involve close corporations. See Caplan v. Lionel Corp., 20 App. Div. 2d 301, 246 N.Y.S.2d 913, affd, 14 N.Y.2d 679, 198 N.E.2d 908, 249 N.Y.S.2d 877 (1964); Avien, Inc. v. Weiss, 50 Misc. 2d 127, 269 N.Y.S.2d 836 (Sup. Ct. 1966).

55. The first seven annual Interim Reports to the New York Legislature of the state's Joint Legislative Committee to Study Revision of Corporation Laws, generally, and the various draft statutes together with the "Revisers' Notes" and "Comment" contained therein.

56. See generally New York State Legislative ANNUAL-1961, at 87 (1961); New YORK State Legislative ANNUAL-1962, at 39 (1962); Philosophies $440-41 \mathrm{nn} .11,12$ (both as'to documents from the legislative history); Lesher, supra note 23; Stevens, supra note 22 (both as to the legislative history generally).

57. It is also recommended that the remaining members of the board of directors be authorized to fill vacancies by an affirmative vote of the majority of them, although such majority is less than a quorum. At least 17 jurisdictions now permit the filling of vacancies by the remaining members of the board although less than a quorum remains. It is fairly well settled that a quorum of the directors may act to fill a vacancy, and a majority vote of such quorum will bind the corporation, whereas, less than a quorum of the board is sometimes considered incapable of acting to fill a vacancy. Recently enacted statutes have sought to avoid any confusion or question on this point by specifically providing, as in the Model Act, that a majority of the affirmative votes of the remaining directors, though less than a quorum, may fill a vacancy. STATE of NEw YoRK JoINT Legislative Committee to Study Revision of Corporation Laws, Consultant's REPORT No. 46, VACANCIES 15-16 (1958) (footnote omitted). 
quorum before the board can act to select new members. ${ }^{58}$ Surely the percentage vote required, after the need for a quorum has been removed, does not present such an unusual problem as to require the unique solution of a different percentage vote than is otherwise required for board action. The quorum problem can be truly insurmountable because a quorum is stated in terms of a fixed number - the authorized directors. ${ }^{59}$ When the number of directors in office drops below the fixed level of a quorum, there can be no legitimate board action without the operation of a special rule such as section 705(a). The percentage vote required for board action, however, is never mathematically insurmountable because it is tied, once a quorum is established, to a variable number-the number of board members present at a particular meeting. ${ }^{60}$ As the number of directors in office drops, the number of directors' votes required to transact an item of business also drops. It might be said that section 705(a) is a statute about quorums and not about votes. In this light it is logical to construe the word "majority" in section 705(a) as a directory minimum, used, much as it is elsewhere in the New York Business Corporation Law, ${ }^{61}$ as a guideline in the absence of some other specification by the parties rather than as a mandatory, fixed percentage to be used in all cases.

Furthermore, the avowed purpose of section 705(a)-that of saving time and money in not requiring a shareholder vote ${ }^{62}$-would seem inapplicable to a close corporation where the directors are often the only shareholders. In a close corporation, a shareholder vote would be as easily taken as a director vote. Section 705(a) is, in this situation, of very limited usefulness, and the section rightfully provides that at the option of the corporation, board vacancies may be filled by a shareholder vote. ${ }^{63}$ There are two pertinent implications from the provisions of this option. First, where the percentage requirement for a shareholder vote is the same as that for a director

58. "The purpose of [\$ 705(a)] is to prevent vacancies in the board from paralyzing the corporation [from lack of a quorum of directors in office]." Avien, Inc. v. Weiss, 50 Misc. 127, 133,269 N.Y.S.2d 836, 843 (Sup. Ct. 1966).

59. See note 4 supra and accompanying text.

60. See note 5 supra and accompanying text.

61. See, e.g., N.Y. Bus. CoRp. LAW $\S \S 608,614,707,708$ (McKinney 1963). These sections are carefully drafted so that it is made obvious that a majority vote is not mandatory.

62. See text accompanying note 23 supra.

63. "[D]irectorships resulting from . . . vacancies . . . may be filled by . . . the directors ... . unless the certificate of incorporation or the by-laws provide that such . . . vacancies shall be filled by vote of the shareholders." Id. § 705(a). 
vote in a close corporation with substantial identity between shareholders and directors, section 705(a) would be totally fruitless. It may even be harmful if the draftsman of the corporate charter and bylaws does not carefully observe that if he does not affirmatively specify that the filling of director vacancies is to be done by shareholder vote, his meticulously drafted high vote or veto provisions may be circumvented by the presence of the majority vote provision of section 705(a). Second, since a corporation can specify in its charter or by-laws that the shareholders, not a majority of the directors, shall fill board vacancies and since under section 616 of the Business Corporation Law a shareholders' high vote requirement is possible, the majority requirement of section 705(a) can be circumvented; hence the majority requirement arguably was not intended to be inflexibly mandatory.

Perhaps Benintendi, through the Jacobson court's construction of section 705(a), has returned to haunt us. ${ }^{64}$ The majority's argument in Jacobson bears, in part, a striking similarity to portions of the court's opinion in Benintendi. The Jacobson court spoke of a state of corporate "futility" and observed that "the vitality of the corporation [is] to be preserved and the paralysis of its functions and mandatory dissolution [are] to be avoided." ${ }^{65}$ The Benintendi court called the high vote requirement before it "unworkable"65 as tending to produce "deadlock" argument, described as "exceedingly weak," repudiated by the enactment of section 9 of the New York Stock Corporation Law in $1948 .{ }^{70}$ The parties to an incorporated or unincorporated partnership are generally aware that their form of organization can lead to deadlock more easily than in a majority-vote situation. They have knowingly entered into such an arrangement; they are desirous of it; they actively want and intend dissolution or some other form of conflict resolution in the event of deadlock. Moreover, the legislature has, after extensive consideration of the matter, given its blessing to such an intent through the enactment of section 709 and its predecessors. There would seem to be little public

\footnotetext{
64. See text accompanying note 38 supra.

65. See note 16 supra.

66. 294 N.Y. $112,119,60$ N.E.2d 829, 831 (1945).

67. Id. at 118,60 N.E.2d at 831 .

68. Id. See also note 37 supra.

69. O'Neal \$ 4.21.

70. See note 36 supra.
} 
interest in not allowing the parties to a close corporation to structure their internal control arrangements as they wish, regardless of whether those arrangements are considered to be less workable or more likely to produce deadlock than other possible arrangements. ${ }^{71}$ Methods of planning and providing for the resolution of deadlock, ${ }^{72}$ such as arbitration, provisional directors, and buy-sell agreements, are by now so well known that there should be no argument that a voting deadlock must inevitably lead to dissolution. Furthermore, dissolution of the corporate form does not always result in absenting from society the economic benefits of the enterprise. That the participants in the Five Ivy Corporation did not, as far as the court's opinion reveals, make provision either inside or outside their corporate charter or by-laws for devices aiding the resolution of deadlock problems may be lamentable, but it should be of no moment in ruling on the Brody election. First, statutory dissolution ${ }^{73}$ is always possible whether or not the participants have provided for special dissolution arrangements ${ }^{74}$ in their corporate documents. Second, dissolution, or deadlock for that matter, is not at issue in this case. Deadlock has not occurred, and if and when it does there is adequate provision in the law to deal with it. The Jacobson court seems to be looking ahead, seeing deadlock if a 75 percent vote-in effect, three out of three directors-is required and trying to deal with the issue before it is presented to the court for resolution. The court has not only dealt with the issue prematurely but also arguably in the wrong manner. If a critical part of the parties' bargain was for each faction to have a veto and if it should become no longer possible to operate the corporation under that arrangement, then quite possibly the corporate venture should come to an end.

Another weak portion of the court's argument is that Five Ivy's high vote and high quorum requirements must either stand or fall together. ${ }^{75}$ No reason is given, and indeed it is hard to imagine one other than their simlarity. To the extent they are similar, however, the similarity cuts both ways. That the two similar provisions are

71. See State of New York Law Revision Commission, RePort of the Law Revision COMMISSION FOR 1948, at 396-97 (1948); O'NEAL § 4.21; 62 HARV. L. REV. 526, 527 (1949); cf.

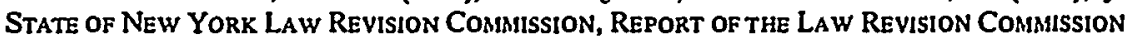
FOR 1948, at 406 (1948).

72. See generally HENN § 277; O'NEAL §§ 1.12,9.01 -.31.

73. See N.Y. Bus. CoRP. LaW § 1104 (McKinney 1963).

74. See, e.g., O'NEAL $\$ 9.06$.

75. See text accompanying note 14 supra. 
alternative and not joint in their operation ${ }^{76}$ and apply at different stages of the corporate decision making process would suggest that if a veto is intended and one form of the veto is taken away, the other veto method should hold strong so that the parties' intent may ultimately be carried out.

Finally, the Jacobson court relied on the venerable rule of statutory and documentary construction that specific provisions govern general ones that deal conflictingly with the same subject. In a vacuum of legislative intent, with no other guidelines as to which of the conflicting provisions should prevail, the specific-general rule might well carry the day. However, in the face of the substantial reasons, ${ }^{77}$ discussed earlier, for application of the high vote reqsirements under section 709(a) rather than the "majority" specified in section 705(a), any presumed statutory construction derived from the specific-general rule would be rebutted. In addition, other doctrines of statutory construction may be cited in favor of the dominance of the high vote requirement in this case. ${ }^{78}$

The old, 1890 statute $^{79}$ governing the filling of board vacancies was more permissive, more attuned to the attitude of the drafters of the Business Corporation Law than is the latter statute itself, at least as interpreted in Jacobson v. Moskowitz. Under the old law, the participants in a corporation could specify any method of filling board vacancies they wished; elections could be by shareholder or director vote and with any desired percentage requirement consistent with the remainder of the statute. The present statute, as literally interpreted in Jacobson, makes the filling of vacancies by a greater than majority vote of directors impossible. ${ }^{80}$ There are three general solutions to the problem created by the statutory conflict as resolved

76. See O'Neal § 4.22.

77. Examples are the statute's laissez-faire or enabling attitude, text accompanying notes 32-48 supra, and the Consultant's Report on vacancies, text accompanying notes 53-57 supra.

78. "The doctrine of the spirit and reason of the law is that principle by which cases within the letter of a statute but without its spirit, are excepted from its [iteral] operation . . . ." F. MCCAfFrey, Statutory Construction $\S 5$, at 12 (1953). "[T] he whole and every part of the statute must be considered in the determination of the meaning of any of its parts." Id. $\S 8$, at 35.

79. See note 20 supra.

80. Although the Jacobson court was not presented with a by-law providing specifically in the by-law itself for a greater than majority directors' vote for filling board vacancies, the court would presumably also invalidate that high vote requirement in favor of section 705(a)'s majority vote requirement. 
in Jacobson. First, section 705(a) could be amended, for example, ${ }^{81}$ by removing the words "a majority of," so as to read "vacancies . . . may be filled by vote of the directors then in office, although less than a quorum exists ...." Reference would be impliedly made to sections 708 and 709 and the particular corporation's charter and bylaws, to determine the percentage "vote" required to transact the business of filling a vacant directorship. Another solution to the problem, short of legislative surgery, would be the judicial overruling of Jacobson v. Moskowitz were a similar case to be presented to the New York courts. A third alternative, although not a complete solution, ${ }^{82}$ is simply careful draftsmanship. This approach obviously also applies in those other states with corporation statutes which are similarly constructed and which provide for a majority vote in filling board vacancies..$^{83}$ In New York, if a veto or high vote is to be maintained, the charter or by-laws must contain a provision specifying that vacant directorships are to be filled by shareholder vote. ${ }^{84}$ This means that if those corporate documents do not contain such a provision, either because they were drafted before the Business Corporation Law came into effect in 1963 and have not been reviewed since then or were not otherwise drafted or reviewed in light of the Jacobson decision, they should now be revised.

In addition to the possibility of drafting for the option of a shareholder vote, two other factors operate to some degree to keep the problem of Jacobson from being drastic. First, the directors elected to fill vacancies are interim directors completing only the unexpired

81. Another possible scheme of statutory amendment would involve addition to, rather than deletion from, the present language of section 705(a). The following are examples, modeled after other provisions in the Business Corporation Law, of clauses which could be added to modify the majority vote provision of section 705(a): "except as otherwise provided in this chapter" (after § 708); "unless a greater proportion is required by the certificate of incorporation or bylaws" (after § 707); "except as otherwise required by this chapter or by the certificate of incorporation as permitted by this chapter" (after $\$ 614$ ).

82. Careful draftsmanship cannot provide for a greater than majority vote of dircetors to fill director vacancies under the present Business Corporation Law as interpreted in Jacobson $v$. Moskowitz. This may not be a great sacrifice sinc, as mentioned earlier, in many close corporations a shareholder vote is as easily had as a director vote due to the substantial identity of the two groups.

83. For potential examples of such states, see $Z$. CAvirch, supra note 19 , at $930 \mathrm{n} .8,931$ n.10, including Georgia: GA. CODE ANN. $\S 22-705$ (a) (1970); Maryland: MD. ANN. CODE art. 23, § 54 (1966); North Carolina: N.C. GEN. STAT. § 55-27 (1965), typographical error corrected, § 55-27 (c) (Supp. 1969); and Virginia: VA. CODE ANN. § 13.1-38 (1964).

84. Shareholders will, of course, have to be given a greater than majority vole under section 616 in order to carry out the veto. 
terms of their predecessors until the next "formal" election of directors by the shareholders. This may or may not be time enough to do the damage that a veto was meant to protect against. Second, "fundamental changes" 85 are reserved as always to the shareholders themselves, in which group any veto originally provided for presumably still exists. This factor may, however, prevent only the most catastrophic changes from being wrought. One minute the overridden incorporated partner is an equal participant by reason of his veto; the next minute he is in a minority position. With no market for the typical close corporation shares, the destiny of his investment becomes locked into the hands of an at least temporarily hostile board of directors. This result is decidedly not what any of the parties bargained for.

85. "Typically, the [fundamental changes] requiring shareholder approval include sale, lease or exchange of all or substantially all the corporate assets outside of the corporation's regular course or business [N.Y. Bus. CORP. LAW $\S 909$ ], amendments of the articles of incorporation and related matters [\$ 803], merger or consolidation [\$ 903], and nonjudicial or voluntary dissolution [§ 1001]." HENN $\S 340$, at 697-98 (footnotes omitted). 
